\title{
Precision Medicine in Hormone Receptor-Positive Breast Cancer
}

\author{
Azadeh Nasrazadani ${ }^{1 *}$, Roby A. Thomas ${ }^{1}$, Steffi Oesterreich ${ }^{2}$ and Adrian V. Lee ${ }^{2}$ \\ ${ }^{1}$ Department of Medicine, University of Pittsburgh, UPMC Hillman Cancer Center, Pittsburgh, PA, United States, \\ ${ }^{2}$ Women's Cancer Research Center, Department of Pharmacology and Chemical Biology, UPMC Hillman Cancer \\ Center, Magee Womens Research Institute, Pittsburgh, PA, United States
}

In recent decades, breast cancer has become largely manageable due to successes with hormone receptor targeting. Hormone receptor-positive tumors have favorable outcomes in comparison to estrogen receptor (ESR1, ER)/progesterone receptor-negative tumors given the targetable nature of these tumors, as well as their inherently less aggressive character. Nonetheless, treatment resistance is frequently encountered due to a variety of mechanisms, including ESR1 mutations and loss of ER expression. A new era of precision medicine utilizes a range of methodologies to allow real-time analysis of individual genomic signatures in metastases and liquid biopsies with the goal of finding clinically actionable targets. Preliminary studies have shown improved progression-free survival

OPEN ACCESS

Edited by: Haim Werner,

Tel Aviv University, Israel

Reviewed by:

Tami Rubinek,

Tel Aviv Sourasky

Medical Center, Israel

Ann M. Moyer,

Mayo Clinic, United States

*Correspondence:

Azadeh Nasrazadani nasrazadania2@upmc.edu

Specialty section: This article was submitted to Cancer Endocrinology,

a section of the journal

Frontiers in Oncology

Received: 07 February 2018 Accepted: 19 April 2018 Published: 04 May 2018

Citation:

Nasrazadani A, Thomas RA, Oesterreich S and Lee AV (2018) Precision Medicine in Hormone Receptor-Positive Breast Cancer.

Front. Oncol. 8:144. doi: 10.3389/fonc.2018.00144 and overall survival with implementation of this information for clinical decision making. In this review, we will discuss the opportunities and challenges in integrating precision medicine through next-generation genomic sequencing into the management of breast cancer.

Keywords: hormone receptor-positive breast cancer, personalized medicine, liquid biopsy, circulating tumor DNA, circulating tumor cells

\section{HORMONE RECEPTOR-POSITIVE DISEASE}

Breast cancer is the most common cancer in US women, and the second leading cause of death. It is estimated that 252,710 women in the US will be diagnosed with invasive breast cancer this year, and 40,610 women will succumb to this disease during this time. Despite these disquieting statistics, relative survival rates are quite high, estimated to be $91 \%$ at 5 years post diagnosis and $80 \%$ at 15 years $(1,2)$. In large part excellent outcomes can be attributed to successes with targeting hormone receptors in hormone receptor-positive disease, which comprises $83 \%$ of invasive breast cancers according to recent data (1).

Hormone receptor inhibition has been pursued as far back as the 1960s, albeit initially with the goal of developing contraceptives. Tamoxifen, initially known as ICI 46474 , was considered a failure when it was found to stimulate rather than suppress ovulation while being investigated for its intended use as an anti-estrogen (3). It was not until the 1970s that it was analyzed for its antitumor effects, obtaining approval for use in advanced breast cancer in 1977. Over time, tamoxifen would gain wide acceptance after studies demonstrated a clear reduction in mortality with use in the adjuvant setting (4-7). Meta-analyses of 15 years follow-up data from randomized trials of patients with ER-positive disease given 5-year adjuvant tamoxifen after 6 months of anthracycline-based chemotherapy have demonstrated an approximately $50 \%$ reduction in breast cancer mortality (8).

Gene expression signatures based on microarray studies have distinguished breast cancer into various molecular intrinsic subtypes (luminal A, luminal B, HER2-like, basal-like, and normal-like); 
however, hormone receptor positivity remains the fundamental feature of this disease $(9,10)$. ER/progesterone receptor (PR) status, specifically, drives the recommendation to initiate hormone targeted therapies, defined as the presence of at least $1 \%$ positive staining in tumor nuclei via immunohistochemistry (IHC) testing $(11,12)$. Standard of care dictates endocrine therapy for patients with ER-positive disease, regardless of other parameters, as per guidelines by ASCO, ESMO, and St. Gallen International Expert Consensus (13-15).

ER expression serves not only as a predictive biomarker for response to endocrine therapy but also provides prognostic value. ER positivity has been found to confer a survival advantage in patients treated with endocrine therapy, specifically tamoxifen, which has not been observed with ER negative disease (5, 16-18). Several reports have documented amplification of estrogen receptor 1 (ESR1), although this remains controversial. Interestingly, ESR1 amplification has not been found to correlate with outcomes in it of itself, although an ER-related transcription signature developed by Symmans et al., termed a sensitivity to endocrine therapy index, demonstrated a significant association with distant relapse-free survival (19).

Tamoxifen is a selective estrogen receptor modulator, exerting inhibitory effects on estrogen signaling by functioning as a competitive inhibitor, promoting ER conformational change, which prevents coactivator binding and thereby hindering propagation of downstream signaling (20). Tamoxifen has been the first-line agent of choice for use in hormone receptor-positive disease for many years. Interestingly, two genetic events that alter generation of estradiol and metabolism of tamoxifen may be important in breast cancer. A recent report indicated that CYP19A1, the aromatase gene responsible for generation of estradiol in postmenopausal women, is amplified in endocrine-resistant breast cancer (21). Tamoxifen is metabolized by CYP2D6 to endoxifen, and evidence suggests that certain CYP2D6 genotypes have reduced metabolism and level of endoxifen, which may be associated with worse outcomes (22). However, this is a controversial area with several studies not supporting this (23). Most recently, the tamoxifen metabolite, endoxifen, has shown promise in a phase I study in women with endocrine refractory metastatic disease, demonstrating a clinical benefit rate or partial response of $26 \%$ (24).

Evidence now supports upfront use of aromatase inhibitors (AIs), specifically in the postmenopausal population. AIs block the synthesis of estrogen from non-ovarian, precursor steroids, and have demonstrated superiority with regard to overall response rates, progression-free survival (PFS), and 10-year mortality rates in comparison to tamoxifen in this population $(25,26)$. The lower incidence of thromboembolic events and vaginal bleeding with AIs further support their use over tamoxifen (27-29).

Selective estrogen receptor degraders (SERDs) encompass an emerging class of hormone receptor-targeted therapies with fulvestrant currently as the only approved agent to date. Fulvestrant inhibits ER dimerization, reducing its nuclear translocation, leading to accelerated receptor degradation and ultimately resulting in the complete suppression of the estrogenic effects on breast tissue (30). Results of the phase III FALCON study comparing use of fulvestrant to anastrozole in advanced hormone receptor-positive breast cancer suggest fulvestrant could be considered in the firstline setting given its noted improvement in PFS (hazard ratio 0.797; median PFS, 16.6 versus 13.8 months, respectively) (31).

Despite tremendous advances in the treatment of hormone receptor-positive breast cancer, resistance remains a critical issue. The Early Breast Cancer Trialists' Collaborative Group recently reported a meta-analysis of 20-year follow-up of 88 clinical trials involving 62,923 women with ER-positive breast cancer treated for 5 years with endocrine therapy (mainly tamoxifen). Importantly, breast cancer recurrences occurred at a steady rate throughout the period of 5-20 years (32). The multiple molecular mechanisms of resistance include alteration of ER expression, dysregulation of co-regulators, and cross talk with growth factor signaling pathways (33).

\section{Her2 (ERRB2)-POSITIVE BREAST CANCER}

HER2 expression serves as a separate yet equally important parameter guiding breast cancer management and is also one of the key mediators of endocrine resistance (33). HER2, initially named neu, was identified as an oncogene as it was found to be activated in ethylnitrosourea-induced rat neuroblastomas (34). It was isolated by multiple groups based on its high homology with $v$-erbB and EGFR, specifically in the ATP-binding domain, but notably found to be distinct from EGFR itself (35-38). HER2 overexpression is demonstrated in approximately one quarter of breast cancers (39), with gene amplification of 2- to 20-fold estimated to occur in $30 \%$ of all breast tumors (40). HER2 gene amplification confers a worse prognosis with shorter time to relapse and a decline in overall survival (OS), correlating with the degree of gene amplification $(40,41)$. Monoclonal antibodies targeting the extracellular domain of HER2 raised in cell lines expressing high HER2 levels showed promise in their ability to inhibit tumor cell proliferation in vitro (42-44) leading to eventual development of a humanized form (45) currently in use as the approved agent trastuzumab.

In patients with HER2-positive metastatic breast cancer (MBC), trastuzumab in combination with standard chemotherapy demonstrated a clear benefit in time to progression, duration of response, and OS as compared to chemotherapy alone (46). A notable 37 and $40 \%$ relative improvement in OS and DFS, respectively, would be demonstrated in women with surgically removed high risk disease receiving trastuzumab as part of standard therapy leading to eventual FDA approval in 2006 (47). Recurrence in this population, however, is not uncommon, prompting development of a range of agents targeting HER2 via distinct mechanisms. Pertuzumab is a humanized monoclonal antibody, which binds the extracellular domain of HER2 as trastuzumab, but at a separate epitope, thereby inhibiting receptor dimerization and preventing downstream signaling (48). The addition of pertuzumab to trastuzumab plus docetaxel in patients with HER2-positive MBC did demonstrate improved median survival by roughly 16 months (49). Lapatinib, an oral tyrosine kinase inhibitor to both epidermal growth factor receptor and HER2 was approved in combination with capecitabine for patients who had prior treatment with Trastuzumab refractory HER2-positive MBC (50). Other HER2-targeted modalities 
are notable for the development of ado-trastuzumab emtansine (T-DM1), an antibody drug conjugated to a cytotoxic agent (DM1). TD-M1 first gained approval when compared to lapatinib with capecitabine in the phase III EMILIA trial with an OS benefit of nearly 6 months (51). Single agent T-DM1 has been shown to significantly increase OS in patients with advanced disease with progression on multiple HER2-targeted therapies per findings from the TH3RESA trial (52). Another tyrosine kinase inhibitor that targets pan-HER2 receptors, neratinib, has recently gained approval in the extended adjuvant setting for patients with HER2positive localized breast cancer based on the ExteNET study (53). Most recently, MYL-14010, a trastuzumab biosimilar developed for the purpose of improving global access and affordability was approved after it was demonstrated to be equivalent to trastuzumab with regard to outcomes and safety parameters (54).

\section{TARGETING OTHER PATHWAYS IN HORMONE RECEPTOR-POSITIVE BREAST CANCER}

The mammalian target of rapamycin (mTOR) pathway has a documented role in ER-resistant disease, with mTOR being of particular interest given its downstream position from the vital PI3K/AKT and Ras/Raf/Mek/Erk signaling pathways [reviewed in Ref. (55)]. Everolimus, a macrolide immunosuppressant and an mTOR inhibitor, has been utilized in treatment of various malignancies. The phase III BOLERO-2 trial demonstrated that everolimus in combination with exemestane, a steroidal AI, showed a median PFS of 7.8 versus 3.2 months for exemestane plus placebo based on investigator assessment (HR 0.45; 95\% CI: 0.38-0.54; $P<0.0001$ ), leading to FDA approval.

In an effort to target common dysregulated pathways in an otherwise highly heterogeneous disease, CDK4/6 inhibitors have come into favor in the recent years given their central role in cell cycle progression and interaction with ER. In an unchecked state in the setting of molecular aberrancy, uncontrolled transcription and proliferation ensues [reviewed in Ref. (56)]. Palbociclib, the first approved of the CDK4/6 inhibitors currently in use, is thought to preferentially inhibit growth in $\mathrm{ER}^{+}$disease based on in vitro findings, which importantly demonstrated enhanced sensitivity in ER-resistant cell lines (57). In phase III PALOMA-2 and PALOMA-3 trials, Palbociclib in combination with an AI or SERD, respectively, demonstrated improvement with regard to PFS but not OS thus far in patients with advanced $\mathrm{HR}^{+} \mathrm{Her} 2^{-}$disease $(58,59)$. Based on these studies, current guidelines advocate for concurrent use of palbociclib with hormone therapy in the first-line setting in patients with metastatic hormone-positive, HER2-negative disease. Subsequent FDA-approved CDK4/6 inhibitors have been similarly found to improve PFS when combined with an $\mathrm{AI}$ in the advanced setting. At an 18-month follow-up, $\mathrm{HR}^{+} \mathrm{Her}^{-}$patients treated with Ribociclib plus letrozole had a $63 \%$ PFS rate, as compared to $42 \%$ in the placebo plus letrozole-treated population (60). Abemaciclib was first studied as a monotherapy in MBC patients with progression on prior lines of therapy, and demonstrated an overall response rate of $19.7 \%$ with a median PFS of 6 months, and median
OS of 17.7 months (61). In the follow-up MONARCH 2 and MONARCH 3 trials, combination of abemaciclib with either fulvestrant or an AI, respectively, has consistently demonstrated an improved PFS when used in the first-line setting in patients with $\mathrm{HR}^{+} \mathrm{Her}^{-}$advanced disease $(62,63)$. Most recently, a meta-analysis including the aforementioned CDK4/6 studies has confirmed the noted improvement in PFS and overall response rate when used in combination with an $\mathrm{AI}$ as first-line therapy in $\mathrm{HR}^{+} \mathrm{Her}^{-}$patients with advanced breast cancer (64). Data are still being collected in relation to the utilization of rapamycin post-CDK4/6 therapy (65).

\section{MOLECULAR EVOLUTION AND ENDOCRINE RESISTANCE IN HORMONE RECEPTOR-POSITIVE DISEASE}

Recent evidence suggests that breast cancers evolve in response to various pressures including those such as lack of nutrients and oxygen, as well as in response to the application of targeted therapies. Part of this evolution is reflected by changes in expression of ER, PR, and HER2, with a meta-analysis indicating that these biomarkers change in approximately $20 \%$ of cases (66). Given this, ASCO recently changed guidelines to indicate that biomarkers should be measured on metastatic tissue if it is available, and therapy can be directed to that measured biomarker (67). Cejalvo et al. recently measured PAM50 intrinsic subtypes in 123 patient-matched pairs of primary and MBC (68). They found no changes in subtype in basal-like tumors, but changes in subtypes in HER2-enriched (23.1\%), luminal B (30.0\%), and in luminal A (55.3\%) breast cancers. Luminal A primary breast cancers often converted to luminal B upon metastasis, and occasionally to from luminal to HER2-enriched. We recently reported similar changes in intrinsic subtypes switching in patient-matched pairs of primary and brain (69) and bone (70) metastases. A challenge of many of these studies is understanding the role of therapy in causing changes in biomarkers, yet a recent study sequencing primary and $\mathrm{MBC}$ in the de novo metastatic therapy naïve setting showed mutational differences (71).

Large international consortia have characterized the mutational landscape of primary breast cancer, and these studies have laid the foundation for detection and targeted therapies against mutations. However, the landscape in MBC remains understudied. Foundation Medicine reported on clinical genomic testing of all coding exons of 287 cancer-related genes plus select introns from 19 genes frequently rearranged in cancer in 18,004 cancers, with a large fraction being advanced cancers (72). They and other groups noted changes in frequency of mutations in $\mathrm{MBC}$ including increased mutation of ESR1 (73-77). Specifically, the Y537S and D538G mutations have been found to confer shortened OS (78). These mutations are in the ligand-binding domain (LBD) and cause ER to exhibit ligand-independent activity. We recently reported recurrent ESR1 gene fusions, where the LBD is removed and the ER becomes constitutively active, in endocrine-resistant breast cancer (79). Several reports have indicated amplification of ESR1 (80), and we recently reported on response to high dose estradiol in a breast cancer with ESR1 amplification (81). 


\section{MONITORING MOLECULAR EVOLUTION AND RESISTANCE IN ER-POSITIVE BREAST CANCER}

Tissue collection becomes a particularly more complicated matter after resection of the primary tumor. Beyond issues with accessibility of metastatic sites, the need to obtain genomic information that is also temporally more reflective of the current state of the tumor has promoted the concept of liquid biopsies to gain favor. Liquid biopsies, which include the collection of circulating tumor cells (CTCs) or cell-free DNA (cfDNA) present in plasma, offer a relatively noninvasive method of monitoring disease, and in many cases, mutational status. CTCs, initially described as far back as 1869 in a postmortem case (82), are generally isolated based on EpCAM expression, and more recently also on physical properties of the CTCs. Cell Search is currently the only system with FDA approval for use in MBC. Methods in development are currently being pursued that instead rely on microfilters and the comparatively larger size of CTCs (83). CTC detection is challenging owing to extremely low frequency in circulation; however, multiple trials have been able to reliably demonstrate presence of CTCs in early and advanced breast cancer. These studies have consistently reported a worse prognosis with regard to PFS and OS with increase in the number of CTCs (84-88).

Cell-free DNA is easier to isolate than CTCs, requiring only a simple isolation of plasma and then DNA extraction. Circulating tumor DNA (ctDNA) can be identified in cfDNA by the presence of mutations that should not be present in normal germline DNA (generally isolated from white blood cells in buffy coat), and can be detected by an ever expanding number of techniques including digital droplet polymerase chain reaction (ddPCR) (89), BEAMing (beads, emulsion, amplification, magnetics) (90, 91), massively parallel sequencing (92), tagged amplicon deep sequencing (93), and the pyrophosphorolysis-activated polymerization method $(94,95)$. Early studies in cell-free tumor DNA present in serum revealed a significantly higher concentration in serum of patients with advanced disease as compared to patients without cancer or with slow growing tumors. Follow-up studies demonstrating decreased strand stability suggested the origin of this DNA is from tumor versus from normal tissue (96). There is debate regarding the exact mechanism of DNA release in plasma, although leading theories support spontaneous release versus apoptosis, and less likely release due to cell lysis or necrosis (97-99). Most recently, studies suggest cfDNA secretion is likely an active process that may occur in association with a protein complex (100). The feasibility of using these techniques for ctDNA detection and subsequent mutational analysis has been verified in multiple tumor types (101-103). In a recent study, analysis of alteration burden in ctDNA was found to predict response in patients with various malignancies receiving checkpoint inhibitors, indicating a more favorable outcome in OS and PFS in tumors with high alteration burden (104). In breast cancer, specifically, serial monitoring of ctDNA has been shown to predict disease recurrence months before metastasis could be clinically detected $(105,106)$, as has been found to be inversely correlated with OS (107).
Progression of disease or recurrence indicate either selection for clones resistant to treatment or evolution of the primary tumor with accumulation of mutations subsequently leading to therapy resistance. In either case, identification and sequencing of culprit mutations provide both a mechanism to predict response to therapies and outcomes, as well as a target to which future therapies can be developed. ddPCR and next-generation sequencing have been utilized by multiple groups to detect ESR 1 hotspot mutations in patients with advanced breast cancer (108) in an appreciable frequency (109-111), and higher in the metastatic setting as compared to micrometastatic disease $(109,112,113)$. Not surprisingly, ESR1 mutations have been demonstrated in patients with ER-positive disease previously exposed to AI therapy and found to confer a shorter PFS with subsequent AI therapy. The incidence of ESR1 mutations were notably more frequent when exposed in the metastatic setting versus during adjuvant AI therapy (113).

\section{GUIDANCE}

Numerous groups are currently documenting molecular evolution in hormone receptor-positive disease, and current evidence indicates that ESR1 is mutated (base pair, amplification, and fusion) in up to $50 \%$ of advanced endocrine-resistant breast cancers. However, the effect of these mutations on prognosis and response to endocrine therapy is unknown and thus the clinical actions to be taken upon the finding of an ESR1 mutation are currently under intense investigation. Outside of ESR1, advanced endocrine-resistant breast cancers harbor mutations in many other pathways, but again the effect of targeting these mutations is currently under investigation. Investigators at Memorial Sloan Kettering Cancer Center recently reported on clinical genomic sequencing of over 10,000 advanced cancers and linked these to the OncoKB database of clinically actionable variants to show which ones have clinical utility (114). They were able to place $11 \%$ of patients on genomic-directed therapy. Lefebvre et al. reported not only on whole-exome sequencing of 216 advanced breast cancers and noted mutation and amplification of ESR1, but also mutation of clinically actionable genes ERBB4, NOTCH3, and ALK (115). Thoughtful agent selection becomes imperative, especially in the metastatic setting when time is more limited. Von Hoff et al. demonstrated an improvement in PFS in a range of refractory metastatic cancers treated with targeted therapies selected based on individualized FISH, microarray, or IHC data (116).

Despite the vast potential for liquid biopsy incorporation in clinical decision making, this field remains in its infancy. Numerous trials are currently underway evaluating the role of plasma ctDNA in both observational capacities to predict response, as well as from interventional perspectives [reviewed in Ref. (117)]. A Precision Oncology Decision Support System has been established at MD Anderson Cancer Center that provides a clinical interpretation service that comments on the clinical significance and actionability of alterations present in a tumor sample (118). Following the results of their recommendations, a small yet clinically significant improvement in OS and DFS was reported in the population in which the genomic panel 
annotations led to a change in therapy (119). A similar model can be envisioned with the use of liquid biopsies to guide selection of therapy as patients progress on their current treatment. Several trials are ongoing and in development, notably IMAGE and IMAGE-II studies initiated at the Sidney Kimmel Comprehensive Cancer Center at John Hopkins, which aim to identify actionable mutations in $\mathrm{MBC}$ as detected in tissue and blood.

Further studies are required to ensure what is gained in convenience in sample collection does not come at the expense of genomic expression concordance between tumor tissue and what is observed in liquid biopsy samples. Intra-heterogeneity demonstrated within individual CTCs from the same patient (120) brings into question the appropriateness of reliance on genomic data obtained from single cells. Furthermore, the limited half-life of circulating nucleic acids in circulation, estimated to be in the range of minutes (121), may greatly influence our ability to detect clinically significant alterations in a timely fashion.

At present, ASCO guidelines strongly recommend against use of data obtained from CTCs to guide decision making with regard to adjuvant systemic therapy (122) and cite a lack of evidence to suggest benefit in the metastatic setting (67). At least with regard to presence of ESR1 mutations, however,

\section{REFERENCES}

1. American Cancer Society. Breast Cancer Facts \& Figures 2017-2018. (2017). Available from: http://www.cancer.org/research/cancerfactsstatistics/breastcancer-facts-figures (Accessed: January 27, 2018).

2. American Cancer Society. Cancer Facts and Figures 2017. (2017). Available from: https://www.cancer.org/content/dam/cancer-org/research/cancer-factsand-statistics/annual-cancer-facts-and-figures/2017/cancer-facts-andfigures-2017.pdf (Accessed: January 27, 2018).

3. Quirke VM. Tamoxifen from failed contraceptive pill to best-selling breast cancer medicine: a case-study in pharmaceutical innovation. Front Pharmacol (2017) 8:620. doi:10.3389/fphar.2017.00620

4. Early Breast Cancer Trialists' Collaborative Group. Effects of adjuvant tamoxifen and of cytotoxic therapy on mortality in early breast cancer. An overview of 61 randomized trials among 28,896 women. N Engl J Med (1988) 319(26):1681-92. doi:10.1056/NEJM198812293192601

5. Early Breast Cancer Trialists' Collaborative Group, Davies C, Godwin J, Gray R, Clarke M, Cutter D, et al. Relevance of breast cancer hormone receptors and other factors to the efficacy of adjuvant tamoxifen: patientlevel meta-analysis of randomised trials. Lancet (2011) 378(9793):771-84. doi:10.1016/S0140-6736(11)60993-8

6. Jordan VC. Tamoxifen: a most unlikely pioneering medicine. Nat Rev Drug Discov (2003) 2(3):205-13. doi:10.1038/nrd1031

7. Jordan VC, Brodie AM. Development and evolution of therapies targeted to the estrogen receptor for the treatment and prevention of breast cancer. Steroids (2007) 72(1):7-25. doi:10.1016/j.steroids.2006.10.009

8. Early Breast Cancer Trialists' Collaborative Group. Effects of chemotherapy and hormonal therapy for early breast cancer on recurrence and 15-year survival: an overview of the randomised trials. Lancet (2005) 365(9472): 1687-717. doi:10.1016/S0140-6736(05)66544-0

9. Perou CM, Sorlie T, Eisen MB, van de Rijn M, Jeffrey SS, Rees CA, et al. Molecular portraits of human breast tumours. Nature (2000) 406(6797): 747-52. doi:10.1038/35021093

10. Sorlie T, Perou CM, Tibshirani R, Aas T, Geisler S, Johnsen H, et al. Gene expression patterns of breast carcinomas distinguish tumor subclasses with clinical implications. Proc Natl Acad Sci U S A (2001) 98(19):10869-74. doi:10.1073/pnas.191367098

11. Duffy MJ, Harbeck N, Nap M, Molina R, Nicolini A, Senkus E, et al. Clinical use of biomarkers in breast cancer: updated guidelines from the European Group
Fribbens et al. report an improvement in PFS in patients with ESR1 mutated, $\mathrm{HR}^{+}$, HER2- $\mathrm{MBC}$ treated with fulvestrant as opposed to exemestane (110).

Current efforts in data collection using liquid biopsies in parallel with evidence-driven recommendations will indisputably provide a wealth of information that will continue to guide the field. As our understanding evolves by way of dynamic monitoring, the goal of utilizing liquid biopsies can approach an eventual reality. In a more real sense, however, an accurate reflection of a tumor profile will likely require incorporation of sources such as both cfDNA and CTCs, as well as RNA-based testing.

\section{AUTHOR CONTRIBUTIONS}

All authors participated in literature review and preparation of the manuscript.

\section{FUNDING}

Research is funded in part by the Fashion Footwear of New York (FFANY), Breast Cancer Research Fund (AL and SO), and UPMC Hillman Cancer Center. SO and AL are Susan G. Komen Scholars, as well as Hillman Foundation Fellows.

on Tumor Markers (EGTM). Eur J Cancer (2017) 75:284-98. doi:10.1016/ j.ejca.2017.01.017

12. Hammond ME, Hayes DF, Dowsett M, Allred DC, Hagerty KL, Badve S, et al. American Society of Clinical Oncology/College of American Pathologists guideline recommendations for immunohistochemical testing of estrogen and progesterone receptors in breast cancer. J Clin Oncol (2010) 28(16):2784-95. doi:10.1200/JCO.2009.25.6529

13. Burstein HJ, Temin S, Anderson H, Buchholz TA, Davidson NE, Gelmon KE, et al. Adjuvant endocrine therapy for women with hormone receptorpositive breast cancer: American Society of Clinical Oncology clinica practice guideline focused update. J Clin Oncol (2014) 32(21):2255-69. doi:10.1200/JCO.2013.54.2258

14. Coates AS, Winer EP, Goldhirsch A, Gelber RD, Gnant M, Piccart-Gebhart M, et al. Tailoring therapies - improving the management of early breast cancer: St Gallen international expert consensus on the primary therapy of early breast cancer 2015. Ann Oncol (2015) 26(8):1533-46. doi:10.1093/annonc/ mdv221

15. Senkus E, Kyriakides S, Ohno S, Penault-Llorca F, Poortmans P, Rutgers E, et al. Primary breast cancer: ESMO clinical practice guidelines for diagnosis, treatment and follow-up. Ann Oncol (2015) 26(Suppl 5):v8-30. doi:10.1093/ annonc/mdv298

16. Barnes DM, Millis RR, Gillett CE, Ryder K, Skilton D, Fentiman IS, et al. The interaction of oestrogen receptor status and pathological features with adjuvant treatment in relation to survival in patients with operable breast cancer: a retrospective study of 2660 patients. Endocr Relat Cancer (2004) 11(1):85-96. doi:10.1677/erc.0.0110085

17. International Breast Cancer Study Group, Colleoni M, Gelber S, Goldhirsch A Aebi S, Castiglione-Gertsch M, et al. Tamoxifen after adjuvant chemotherapy for premenopausal women with lymph node-positive breast cancer: international breast cancer study group trial 13-93. J Clin Oncol (2006) 24(9):1332-41. doi:10.1200/JCO.2005.03.0783

18. Khoshnoud MR, Fornander T, Johansson H, Rutqvist LE. Long-term pattern of disease recurrence among patients with early-stage breast cancer according to estrogen receptor status and use of adjuvant tamoxifen. Breast Cancer Res Treat (2008) 107(1):71-8. doi:10.1007/s10549-0079520-0

19. Symmans WF, Hatzis C, Sotiriou C, Andre F, Peintinger F, Regitnig P, et al. Genomic index of sensitivity to endocrine therapy for breast cancer. J Clin Oncol (2010) 28(27):4111-9. doi:10.1200/JCO.2010.28.4273 
20. Shiau AK, Barstad D, Loria PM, Cheng L, Kushner PJ, Agard DA, et al. The structural basis of estrogen receptor/coactivator recognition and the antagonism of this interaction by tamoxifen. Cell (1998) 95(7):927-37. doi:10.1016/S0092-8674(00)81717-1

21. Magnani L, Frige G, Gadaleta RM, Corleone G, Fabris S, Kempe MH, et al. Acquired CYP19A1 amplification is an early specific mechanism of aromatase inhibitor resistance in ERalpha metastatic breast cancer. Nat Genet (2017) 49(3):444-50. doi:10.1038/ng.3773

22. Baatjes KJ, Conradie M, Apffelstaedt JP, Kotze MJ. Pharmacogenetics of aromatase inhibitors in endocrine responsive breast cancer: lessons learnt from tamoxifen and CYP2D6 genotyping. Anticancer Agents Med Chem (2017) 17(13):1805-13. doi:10.2174/1871521409666170412124226

23. Hertz DL, Kidwell KM, Hilsenbeck SG, Oesterreich S, Osborne CK, Philips S, et al. CYP2D6 genotype is not associated with survival in breast cancer patients treated with tamoxifen: results from a population-based study. Breast Cancer Res Treat (2017) 166(1):277-87. doi:10.1007/s10549017-4400-8

24. Goetz MP, Suman VJ, Reid JM, Northfelt DW, Mahr MA, Ralya AT, et al. First-in-human phase I study of the tamoxifen metabolite Z-endoxifen in women with endocrine-refractory metastatic breast cancer. J Clin Oncol (2017) 35(30):3391-400. doi:10.1200/JCO.2017.73.3246

25. Early Breast Cancer Trialists' Collaborative Group. Aromatase inhibitors versus tamoxifen in early breast cancer: patient-level meta-analysis of the randomised trials. Lancet (2015) 386(10001):1341-52. doi:10.1016/S0140-6736 (15)61074-1

26. Paridaens RJ, Dirix LY, Beex LV, Nooij M, Cameron DA, Cufer T, et al. Phase III study comparing exemestane with tamoxifen as first-line hormonal treatment of metastatic breast cancer in postmenopausal women: the European Organisation for Research and Treatment of Cancer breast cancer cooperative group. J Clin Oncol (2008) 26(30):4883-90. doi:10.1200/JCO.2007. 14.4659

27. Bonneterre J, Thurlimann B, Robertson JF, Krzakowski M, Mauriac L, Koralewski P, et al. Anastrozole versus tamoxifen as first-line therapy for advanced breast cancer in 668 postmenopausal women: results of the tamoxifen or arimidex randomized group efficacy and tolerability study. J Clin Oncol (2000) 18(22):3748-57. doi:10.1200/JCO.2000.18.22.3748

28. Vergote I, Bonneterre J, Thurlimann B, Robertson J, Krzakowski M, Mauriac L, et al. Randomised study of anastrozole versus tamoxifen as first-line therapy for advanced breast cancer in postmenopausal women. Eur J Cancer (2000) 36(Suppl 4):S84-5. doi:10.1016/S0959-8049(00)00239-2

29. Walker AJ, West J, Card TR, Crooks C, Kirwan CC, Grainge MJ. When are breast cancer patients at highest risk of venous thromboembolism? A cohort study using English health care data. Blood (2016) 127(7):849-57; quiz 953. doi:10.1182/blood-2015-01-625582

30. Carlson RW. The history and mechanism of action of fulvestrant. Clin Breast Cancer (2005) 6(Suppl 1):S5-8. doi:10.3816/CBC.2005.s.008

31. Robertson JFR, Bondarenko IM, Trishkina E, Dvorkin M, Panasci L, Manikhas A, et al. Fulvestrant $500 \mathrm{mg}$ versus anastrozole $1 \mathrm{mg}$ for hormone receptor-positive advanced breast cancer (FALCON): an international, randomised, double-blind, phase 3 trial. Lancet (2016) 388(10063):2997-3005. doi:10.1016/S0140-6736(16)32389-3

32. Pan H, Gray R, Braybrooke J, Davies C, Taylor C, McGale P, et al. 20-year risks of breast-cancer recurrence after stopping endocrine therapy at 5 years. N Engl J Med (2017) 377(19):1836-46. doi:10.1056/NEJMoa1701830

33. Osborne CK, Schiff R. Mechanisms of endocrine resistance in breast cancer. Annu Rev Med (2011) 62:233-47. doi:10.1146/annurev-med-070909182917

34. Shih C, Padhy LC, Murray M, Weinberg RA. Transforming genes of carcinomas and neuroblastomas introduced into mouse fibroblasts. Nature (1981) 290(5803):261-4. doi:10.1038/290261a0

35. Coussens L, Yang-Feng TL, Liao YC, Chen E, Gray A, McGrath J, et al. Tyrosine kinase receptor with extensive homology to EGF receptor shares chromosomal location with neu oncogene. Science (1985) 230(4730):1132-9. doi:10.1126/science.2999974

36. King CR, Kraus MH, Aaronson SA. Amplification of a novel v-erbB-related gene in a human mammary carcinoma. Science (1985) 229(4717):974-6. doi:10.1126/science.2992089

37. Schechter AL, Hung MC, Vaidyanathan L, Weinberg RA, Yang-Feng TL, Francke $\mathrm{U}$, et al. The neu gene: an erbB-homologous gene distinct from and unlinked to the gene encoding the EGF receptor. Science (1985) 229(4717):976-8. doi:10.1126/science.2992090

38. Semba K, Kamata N, Toyoshima K, Yamamoto T. A v-erbB-related protooncogene, c-erbB-2, is distinct from the c-erbB-1/epidermal growth factorreceptor gene and is amplified in a human salivary gland adenocarcinoma. Proc Natl Acad Sci U S A (1985) 82(19):6497-501. doi:10.1073/pnas.82. 19.6497

39. Witton CJ, Reeves JR, Going JJ, Cooke TG, Bartlett JM. Expression of the HER1-4 family of receptor tyrosine kinases in breast cancer. J Pathol (2003) 200(3):290-7. doi:10.1002/path.1370

40. Slamon DJ, Clark GM, Wong SG, Levin WJ, Ullrich A, McGuire WL. Human breast cancer: correlation of relapse and survival with amplification of the HER-2/neu oncogene. Science (1987) 235(4785):177-82. doi:10.1126/ science. 3798106

41. Xuan Q, Ji H, Tao X, Xu Y, Zhang Q. Quantitative assessment of HER2 amplification in HER2-positive breast cancer: its association with clinical outcomes. Breast Cancer Res Treat (2015) 150(3):581-8. doi:10.1007/s10549015-3334-2

42. Harwerth IM, Wels W, Marte BM, Hynes NE. Monoclonal antibodies against the extracellular domain of the erbB-2 receptor function as partial ligand agonists. J Biol Chem (1992) 267(21):15160-7.

43. Harwerth IM, Wels W, Schlegel J, Muller M, Hynes NE. Monoclonal antibodies directed to the erbB-2 receptor inhibit in vivo tumour cell growth. $\mathrm{Br}$ J Cancer (1993) 68(6):1140-5. doi:10.1038/bjc.1993.494

44. Hudziak RM, Lewis GD, Winget M, Fendly BM, Shepard HM, Ullrich A. p185HER2 monoclonal antibody has antiproliferative effects in vitro and sensitizes human breast tumor cells to tumor necrosis factor. $\mathrm{Mol}$ Cell Biol (1989) 9(3):1165-72. doi:10.1128/MCB.9.3.1165

45. Carter P, Presta L, Gorman CM, Ridgway JB, Henner D, Wong WL, et al. Humanization of an anti-p185HER2 antibody for human cancer therapy. Proc Natl Acad Sci U S A (1992) 89(10):4285-9. doi:10.1073/pnas.89.10.4285

46. Slamon DJ, Leyland-Jones B, Shak S, Fuchs H, Paton V, Bajamonde A, et al. Use of chemotherapy plus a monoclonal antibody against HER2 for metastatic breast cancer that overexpresses HER2. N Engl J Med (2001) 344(11):783-92. doi:10.1056/NEJM200103153441101

47. Perez EA, Romond EH, Suman VJ, Jeong JH, Sledge G, Geyer CE Jr, et al. Trastuzumab plus adjuvant chemotherapy for human epidermal growth factor receptor 2-positive breast cancer: planned joint analysis of overall survival from NSABP B-31 and NCCTG N9831. J Clin Oncol (2014) 32(33):3744-52. doi:10.1200/JCO.2014.55.5730

48. Harbeck N, Beckmann MW, Rody A, Schneeweiss A, Muller V, Fehm T, et al. HER2 dimerization inhibitor pertuzumab - mode of action and clinical data in breast cancer. Breast Care (Basel) (2013) 8(1):49-55. doi:10.1159/ 000346837

49. Swain SM, Baselga J, Kim SB, Ro J, Semiglazov V, Campone M, et al. Pertuzumab, trastuzumab, and docetaxel in HER2-positive metastatic breast cancer. N Engl J Med (2015) 372(8):724-34. doi:10.1056/NEJMoa1413513

50. Geyer CE, Forster J, Lindquist D, Chan S, Romieu CG, Pienkowski T, et al. Lapatinib plus capecitabine for HER2-positive advanced breast cancer. N Engl J Med (2006) 355(26):2733-43. doi:10.1056/NEJMoa064320

51. Verma S, Miles D, Gianni L, Krop IE, Welslau M, Baselga J, et al. Trastuzumab emtansine for HER2-positive advanced breast cancer. N Engl J Med (2012) 367(19):1783-91. doi:10.1056/NEJMoa1209124

52. Krop IE, Kim SB, Martin AG, LoRusso PM, Ferrero JM, Badovinac-Crnjevic T, et al. Trastuzumab emtansine versus treatment of physician's choice in patients with previously treated HER2-positive metastatic breast cancer (TH3RESA): final overall survival results from a randomised open-label phase 3 trial. Lancet Oncol (2017) 18(6):743-54. doi:10.1016/S1470-2045 (17)30313-3

53. Chan A, Delaloge S, Holmes FA, Moy B, Iwata H, Harvey VJ, et al. Neratinib after trastuzumab-based adjuvant therapy in patients with HER2-positive breast cancer (ExteNET): a multicentre, randomised, double-blind, placebocontrolled, phase 3 trial. Lancet Oncol (2016) 17(3):367-77. doi:10.1016/ S1470-2045(15)00551-3

54. Rugo HS, Barve A, Waller CF, Hernandez-Bronchud M, Herson J, Yuan J, et al. Effect of a proposed trastuzumab biosimilar compared with trastuzumab on overall response rate in patients with ERBB2 (HER2)-positive metastatic breast cancer: a randomized clinical trial. JAMA (2017) 317(1):37-47 doi:10.1001/jama.2016.18305 
55. Liu J, Li HQ, Zhou FX, Yu JW, Sun L, Han ZH. Targeting the mTOR pathway in breast cancer. Tumour Biol (2017) 39(6):1-15. doi:10.1177/1010428317710825

56. Murphy CG, Dickler MN. The role of CDK4/6 inhibition in breast cancer. Oncologist (2015) 20(5):483-90. doi:10.1634/theoncologist.2014-0443

57. Finn RS, Dering J, Conklin D, Kalous O, Cohen DJ, Desai AJ, et al. PD 0332991, a selective cyclin D kinase 4/6 inhibitor, preferentially inhibits proliferation of luminal estrogen receptor-positive human breast cancer cell lines in vitro. Breast Cancer Res (2009) 11(5):R77. doi:10.1186/bcr2419

58. Cristofanilli M, Turner NC, Bondarenko I, Ro J, Im SA, Masuda N, et al. Fulvestrant plus palbociclib versus fulvestrant plus placebo for treatment of hormone-receptor-positive, HER2-negative metastatic breast cancer that progressed on previous endocrine therapy (PALOMA-3): final analysis of the multicentre, double-blind, phase 3 randomised controlled trial. Lancet Oncol (2016) 17(4):425-39. doi:10.1016/S1470-2045(15)00613-0

59. Finn RS, Martin M, Rugo HS, Jones S, Im SA, Gelmon K, et al. Palbociclib and letrozole in advanced breast cancer. N Engl J Med (2016) 375(20):1925-36. doi:10.1056/NEJMoa1607303

60. Hortobagyi GN, Stemmer SM, Burris HA, Yap YS, Sonke GS, Paluch-Shimon S, et al. Ribociclib as first-line therapy for HR-positive, advanced breast cancer. N Engl J Med (2016) 375(18):1738-48. doi:10.1056/NEJMoa1609709

61. Dickler MN, Tolaney SM, Rugo HS, Cortes J, Dieras V, Patt D, et al. MONARCH 1, a phase II study of abemaciclib, a CDK4 and CDK6 inhibitor, as a single agent, in patients with refractory $\mathrm{HR}(+) / \mathrm{HER} 2(-)$ metastatic breast cancer. Clin Cancer Res (2017) 23(17):5218-24. doi:10.1158/10780432.CCR-17-0754

62. Goetz MP, Toi M, Campone M, Sohn J, Paluch-Shimon S, Huober J, et al. MONARCH 3: abemaciclib as initial therapy for advanced breast cancer. J Clin Oncol (2017) 35(32):3638-46. doi:10.1200/JCO.2017.75.6155

63. Sledge GW Jr, Toi M, Neven P, Sohn J, Inoue K, Pivot X, et al. MONARCH 2: abemaciclib in combination with fulvestrant in women with $\mathrm{HR}+$ / HER2- advanced breast cancer who had progressed while receiving endocrine therapy. JClin Oncol (2017) 35(25):2875-84. doi:10.1200/JCO.2017. 73.7585

64. Ramos-Esquivel A, Hernandez-Steller H, Savard MF, Landaverde DU. Cyclindependent kinase $4 / 6$ inhibitors as first-line treatment for post-menopausal metastatic hormone receptor-positive breast cancer patients: a systematic review and meta-analysis of phase III randomized clinical trials. Breast Cancer (2018). doi:10.1007/s12282-018-0848-6

65. Baselga J, Cortes J, Kim SB, Im SA, Hegg R, Im YH, et al. Pertuzumab plus trastuzumab plus docetaxel for metastatic breast cancer. N Engl J Med (2012) 366(2):109-19. doi:10.1056/NEJMoa1113216

66. Schrijver W, Suijkerbuijk KPM, van Gils CH, van der Wall E, Moelans CB, van Diest PJ. Receptor conversion in distant breast cancer metastases: a systematic review and meta-analysis. J Natl Cancer Inst (2018). doi:10.1093/ jnci/djx273

67. Van Poznak C, Somerfield MR, Bast RC, Cristofanilli M, Goetz MP, GonzalezAngulo AM, et al. Use of biomarkers to guide decisions on systemic therapy for women with metastatic breast cancer: American Society of Clinical Oncology clinical practice guideline. J Clin Oncol (2015) 33(24):2695-704. doi:10.1200/JCO.2015.61.1459

68. Cejalvo JM, Martinez de Duenas E, Galvan P, Garcia-Recio S, Burgues Gasion O, Pare L, et al. Intrinsic subtypes and gene expression profiles in primary and metastatic breast cancer. Cancer Res (2017) 77(9):2213-21. doi:10.1158/0008-5472.CAN-16-2717

69. Priedigkeit N, Hartmaier RJ, Chen Y, Vareslija D, Basudan A, Watters RJ, et al. Intrinsic subtype switching and acquired ERBB2/HER2 amplifications and mutations in breast cancer brain metastases. JAMA Oncol (2017) 3(5):666-71. doi:10.1001/jamaoncol.2016.5630

70. Priedigkeit N, Watters RJ, Lucas PC, Basudan A, Bhargava R, Horne W, et al. Exome-capture RNA sequencing of decade-old breast cancers and matched decalcified bone metastases. JCI Insight (2017) 2(17):95703. doi:10.1172/jci. insight.95703

71. Ng CKY, Bidard FC, Piscuoglio S, Geyer FC, Lim RS, de Bruijn I, et al. Genetic heterogeneity in therapy-naive synchronous primary breast cancers and their metastases. Clin Cancer Res (2017) 23(15):4402-15. doi:10.1158/1078-0432. CCR-16-3115

72. Hartmaier RJ, Albacker LA, Chmielecki J, Bailey M, He J, Goldberg ME, et al. High-throughput genomic profiling of adult solid tumors reveals novel insights into cancer pathogenesis. Cancer Res (2017) 77(9):2464-75. doi:10.1158/0008-5472.CAN-16-2479

73. Jeselsohn R, Yelensky R, Buchwalter G, Frampton G, Meric-Bernstam F, Gonzalez-Angulo AM, et al. Emergence of constitutively active estrogen receptor-alpha mutations in pretreated advanced estrogen receptor-positive breast cancer. Clin Cancer Res (2014) 20(7):1757-67. doi:10.1158/1078-0432. CCR-13-2332

74. Li S, Shen D, Shao J, Crowder R, Liu W, Prat A, et al. Endocrine-therapyresistant ESR1 variants revealed by genomic characterization of breastcancer-derived xenografts. Cell Rep (2013) 4(6):1116-30. doi:10.1016/j. celrep.2013.08.022

75. Merenbakh-Lamin K, Ben-Baruch N, Yeheskel A, Dvir A, Soussan-Gutman L, Jeselsohn R, et al. D538G mutation in estrogen receptor-alpha: a novel mechanism for acquired endocrine resistance in breast cancer. Cancer Res (2013) 73(23):6856-64. doi:10.1158/0008-5472.CAN-13-1197

76. Robinson DR, Wu YM, Vats P, Su F, Lonigro RJ, Cao X, et al. Activating ESR1 mutations in hormone-resistant metastatic breast cancer. Nat Genet (2013) 45(12):1446-51. doi:10.1038/ng.2823

77. Toy W, Shen Y, Won H, Green B, Sakr RA, Will M, et al. ESR1 ligand-binding domain mutations in hormone-resistant breast cancer. Nat Genet (2013) 45(12):1439-45. doi:10.1038/ng.2822

78. Chandarlapaty S, Chen D, He W, Sung P, Samoila A, You D, et al. Prevalence of ESR1 mutations in cell-free DNA and outcomes in metastatic breast cancer: a secondary analysis of the BOLERO-2 clinical trial. JAMA Oncol (2016) 2(10):1310-5. doi:10.1001/jamaoncol.2016.1279

79. Hartmaier RJ, Trabucco SE, Priedigkeit N, Chung JH, Parachoniak CA, Vanden Borre P, et al. Recurrent hyperactive ESR1 fusion proteins in endocrine therapy resistant breast cancer. Ann Oncol (2018). doi:10.1093/annonc/ mdy025

80. Holst F. Estrogen receptor alpha gene amplification in breast cancer: 25 years of debate. World J Clin Oncol (2016) 7(2):160-73. doi:10.5306/wjco.v7.i2.160

81. Kota K, Brufsky A, Oesterreich S, Lee A. Estradiol as a targeted, late-line therapy in metastatic breast cancer with estrogen receptor amplification. Cureus (2017) 9(7):e1434. doi:10.7759/cureus.1434

82. Ashworth T. A case of cancer in which cells similar to those in the tumors were seen in the blood after death. Aust Med J (1869) 14:146-9.

83. Lin HK, Zheng S, Williams AJ, Balic M, Groshen S, Scher HI, et al. Portable filter-based microdevice for detection and characterization of circulating tumor cells. Clin Cancer Res (2010) 16(20):5011-8. doi:10.1158/1078-0432. CCR-10-1105

84. Bidard FC, Belin L, Delaloge S, Lerebours F, Ngo C, Reyal F, et al. Timedependent prognostic impact of circulating tumor cells detection in non-metastatic breast cancer: 70-month analysis of the REMAGUS02 study. Int J Breast Cancer (2013) 2013:130470. doi:10.1155/2013/130470

85. Cristofanilli M, Budd GT, Ellis MJ, Stopeck A, Matera J, Miller MC, et al. Circulating tumor cells, disease progression, and survival in metastatic breast cancer. N Engl J Med (2004) 351(8):781-91. doi:10.1056/NEJMoa040766

86. Helissey C, Berger F, Cottu P, Dieras V, Mignot L, Servois V, et al. Circulating tumor cell thresholds and survival scores in advanced metastatic breast cancer: the observational step of the CirCe01 phase III trial. Cancer Lett (2015) 360(2):213-8. doi:10.1016/j.canlet.2015.02.010

87. Rack B, Schindlbeck C, Juckstock J, Andergassen U, Hepp P, Zwingers T, et al. Circulating tumor cells predict survival in early average-to-high risk breast cancer patients. J Natl Cancer Inst (2014) 106(5):dju066. doi:10.1093/ jnci/dju066

88. Riethdorf S, Fritsche H, Muller V, Rau T, Schindlbeck C, Rack B, et al. Detection of circulating tumor cells in peripheral blood of patients with metastatic breast cancer: a validation study of the CellSearch system. Clin Cancer Res (2007) 13(3):920-8. doi:10.1158/1078-0432.CCR-06-1695

89. Vogelstein B, Kinzler KW. Digital PCR. Proc Natl Acad Sci U S A (1999) 96(16):9236-41. doi:10.1073/pnas.96.16.9236

90. Diehl F, Schmidt K, Choti MA, Romans K, Goodman S, Li M, et al. Circulating mutant DNA to assess tumor dynamics. Nat Med (2008) 14(9):985-90. doi:10.1038/nm.1789

91. Dressman D, Yan H, Traverso G, Kinzler KW, Vogelstein B. Transforming single DNA molecules into fluorescent magnetic particles for detection and enumeration of genetic variations. Proc Natl Acad Sci U S A (2003) 100(15):8817-22. doi:10.1073/pnas. 1133470100 
92. Gundry M, Vijg J. Direct mutation analysis by high-throughput sequencing: from germline to low-abundant, somatic variants. Mutat Res (2012) 729(1-2):1-15. doi:10.1016/mrfmmm.2011.10.001

93. Forshew T, Murtaza M, Parkinson C, Gale D, Tsui DW, Kaper F, et al. Noninvasive identification and monitoring of cancer mutations by targeted deep sequencing of plasma DNA. Sci Transl Med (2012) 4(136):136ra168. doi:10.1126/scitranslmed.3003726

94. Liu Q, Sommer SS. Pyrophosphorolysis-activated polymerization (PAP): application to allele-specific amplification. Biotechniques (2000) 29(5): 1072-6, 1078, 1080 passim.

95. Leon SA, Shapiro B, Sklaroff DM, Yaros MJ. Free DNA in the serum of cancer patients and the effect of therapy. Cancer Res (1977) 37(3):646-50.

96. Stroun M, Anker P, Maurice P, Lyautey J, Lederrey C, Beljanski M. Neoplastic characteristics of the DNA found in the plasma of cancer patients. Oncology (1989) 46(5):318-22. doi:10.1159/000226740

97. Abolhassani M, Tillotson J, Chiao J. Characterization of the release of DNA by a human leukemia-cell line hl-60. Int J Oncol (1994) 4(2):417-21.

98. Stroun M, Lyautey J, Lederrey C, Olson-Sand A, Anker P. About the possible origin and mechanism of circulating DNA apoptosis and active DNA release. Clin Chim Acta (2001) 313(1-2):139-42. doi:10.1016/S00098981(01)00665-9

99. Stroun M, Maurice P, Vasioukhin V, Lyautey J, Lederrey C, Lefort F, et al. The origin and mechanism of circulating DNA. Ann N Y Acad Sci (2000) 906:161-8. doi:10.1111/j.1749-6632.2000.tb06608.x

100. Bronkhorst AJ, Wentzel JF, Aucamp J, van Dyk E, du Plessis L, Pretorius PJ. Characterization of the cell-free DNA released by cultured cancer cells. Biochim Biophys Acta (2016) 1863(1):157-65. doi:10.1016/j.bbamcr.2015. 10.022

101. Bettegowda C, Sausen M, Leary RJ, Kinde I, Wang Y, Agrawal N, et al. Detection of circulating tumor DNA in early- and late-stage human malignancies. Sci Transl Med (2014) 6(224):224ra224. doi:10.1126/scitranslmed. 3007094

102. Leary RJ, Sausen M, Kinde I, Papadopoulos N, Carpten JD, Craig D, et al. Detection of chromosomal alterations in the circulation of cancer patients with whole-genome sequencing. Sci Transl Med (2012) 4(162):162ra154. doi:10.1126/scitranslmed.3004742

103. Thompson JC, Yee SS, Troxel AB, Savitch SL, Fan R, Balli D, et al. Detection of therapeutically targetable driver and resistance mutations in lung cancer patients by next-generation sequencing of cell-free circulating tumor DNA. Clin Cancer Res (2016) 22(23):5772-82. doi:10.1158/1078-0432.CCR16-1231

104. Khagi Y, Goodman AM, Daniels GA, Patel SP, Sacco AG, Randall JM, et al. Hypermutated circulating tumor DNA: correlation with response to checkpoint inhibitor-based immunotherapy. Clin Cancer Res (2017) 23(19): 5729-36. doi:10.1158/1078-0432.CCR-17-1439

105. Garcia-Murillas I, Schiavon G, Weigelt B, Ng C, Hrebien S, Cutts RJ, et al. Mutation tracking in circulating tumor DNA predicts relapse in early breast cancer. Sci Transl Med (2015) 7(302):302ra133. doi:10.1126/scitranslmed. aab0021

106. Olsson E, Winter C, George A, Chen Y, Howlin J, Tang MH, et al. Serial monitoring of circulating tumor DNA in patients with primary breast cancer for detection of occult metastatic disease. EMBO Mol Med (2015) 7(8):1034-47. doi:10.15252/emmm.201404913

107. Dawson SJ, Tsui DW, Murtaza M, Biggs H, Rueda OM, Chin SF, et al. Analysis of circulating tumor DNA to monitor metastatic breast cancer. $N$ Engl J Med (2013) 368(13):1199-209. doi:10.1056/NEJMoa1213261

108. Oesterreich S, Davidson NE. The search for ESR1 mutations in breast cancer. Nat Genet (2013) 45(12):1415-6. doi:10.1038/ng.2831

109. Chu D, Paoletti C, Gersch C, VanDenBerg DA, Zabransky DJ, Cochran RL, et al. ESR1 mutations in circulating plasma tumor DNA from metastatic breast cancer patients. Clin Cancer Res (2016) 22(4):993-9. doi:10.1158/1078-0432. CCR-15-0943
110. Fribbens C, O'Leary B, Kilburn L, Hrebien S, Garcia-Murillas I, Beaney M, et al. Plasma ESR1 mutations and the treatment of estrogen receptor-positive advanced breast cancer. J Clin Oncol (2016) 34(25):2961-8. doi:10.1200/ JCO.2016.67.3061

111. Wang P, Bahreini A, Gyanchandani R, Lucas PC, Hartmaier RJ, Watters RJ, et al. Sensitive detection of mono- and polyclonal ESR1 mutations in primary tumors, metastatic lesions, and cell-free DNA of breast cancer patients. Clin Cancer Res (2016) 22(5):1130-7. doi:10.1158/1078-0432.CCR-15-1534

112. Guttery DS, Page K, Hills A, Woodley L, Marchese SD, Rghebi B, et al. Noninvasive detection of activating estrogen receptor 1 (ESR1) mutations in estrogen receptor-positive metastatic breast cancer. Clin Chem (2015) 61(7):974-82. doi:10.1373/clinchem.2015.238717

113. Schiavon G, Hrebien S, Garcia-Murillas I, Cutts RJ, Pearson A, Tarazona N, et al. Analysis of ESR1 mutation in circulating tumor DNA demonstrates evolution during therapy for metastatic breast cancer. Sci Transl Med (2015) 7(313):313ra182. doi:10.1126/scitranslmed.aac7551

114. Zehir A, Benayed R, Shah RH, Syed A, Middha S, Kim HR, et al. Mutational landscape of metastatic cancer revealed from prospective clinical sequencing of 10,000 patients. Nat Med (2017) 23(6):703-13. doi:10.1038/ nm.4333

115. Lefebvre C, Bachelot T, Filleron T, Pedrero M, Campone M, Soria JC, et al. Mutational profile of metastatic breast cancers: a retrospective analysis. PLoS Med (2016) 13(12):e1002201. doi:10.1371/journal.pmed.1002201

116. Von Hoff DD, Stephenson JJ Jr, Rosen P, Loesch DM, Borad MJ, Anthony S, et al. Pilot study using molecular profiling of patients' tumors to find potential targets and select treatments for their refractory cancers. J Clin Oncol (2010) 28(33):4877-83. doi:10.1200/JCO.2009.26.5983

117. Appierto V, Di Cosimo S, Reduzzi C, Pala V, Cappelletti V, Daidone MG. How to study and overcome tumor heterogeneity with circulating biomarkers: the breast cancer case. Semin Cancer Biol (2017) 44:106-16. doi:10.1016/j. semcancer.2017.04.007

118. Johnson A, Khotskaya YB, Brusco L, Zeng J, Holla V, Bailey AM, et al. Clinical use of precision oncology decision support. JCO Precis Oncol (2017) 1:1-12. doi:10.1200/PO.17.00036

119. Tsimberidou AM, Hong DS, Ye Y, Cartwright C, Wheler JJ, Falchook GS, et al. Initiative for molecular profiling and advanced cancer therapy (IMPACT): an MD Anderson precision medicine study. JCO Precis Oncol (2017) 2017:1-24. doi:10.1200/PO.17.00002

120. De Luca F, Rotunno G, Salvianti F, Galardi F, Pestrin M, Gabellini S, et al. Mutational analysis of single circulating tumor cells by next generation sequencing in metastatic breast cancer. Oncotarget (2016) 7(18):26107-19. doi:10.18632/oncotarget.8431

121. Fleischhacker M, Schmidt B. Circulating nucleic acids (CNAs) and cancer a survey. Biochim Biophys Acta (2007) 1775(1):181-232. doi:10.1016/j.bbcan. 2006.10.001

122. Harris LN, Ismaila N, McShane LM, Andre F, Collyar DE, Gonzalez-Angulo AM, et al. Use of biomarkers to guide decisions on adjuvant systemic therapy for women with early-stage invasive breast cancer: American Society of Clinical Oncology clinical practice guideline. J Clin Oncol (2016) 34(10):1134-50. doi:10.1200/JCO.2015.65.2289

Conflict of Interest Statement: The authors declare that the research was conducted in the absence of any commercial or financial relationships that could be construed as a potential conflict of interest.

Copyright (C) 2018 Nasrazadani, Thomas, Oesterreich and Lee. This is an openaccess article distributed under the terms of the Creative Commons Attribution License (CC BY). The use, distribution or reproduction in other forums is permitted, provided the original author(s) and the copyright owner are credited and that the original publication in this journal is cited, in accordance with accepted academic practice. No use, distribution or reproduction is permitted which does not comply with these terms. 